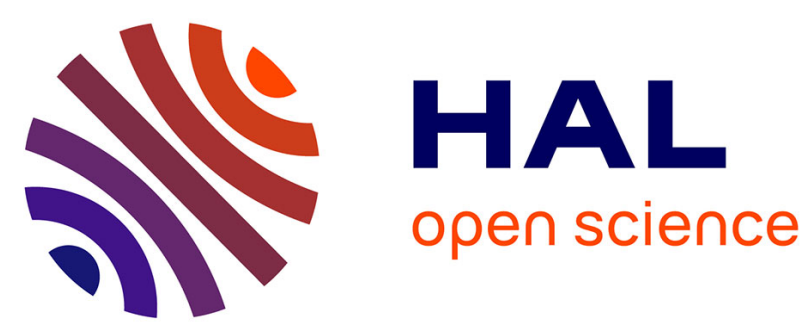

\title{
Polymorphic variations in exon 10 of the Luteinizing Hormone Receptor: Functional consequences and associations with breast cancer
}

Djura Piersma, Miriam Verhoef-Post, Maxime P. Look, André G. Uitterlinden, Huibert A.P. Pols, Els M.J.J. Berns, Axel P.N. Themmen

\section{To cite this version:}

Djura Piersma, Miriam Verhoef-Post, Maxime P. Look, André G. Uitterlinden, Huibert A.P. Pols, et al.. Polymorphic variations in exon 10 of the Luteinizing Hormone Receptor: Functional consequences and associations with breast cancer. Molecular and Cellular Endocrinology, 2007, 276 (1-2), pp.63. 10.1016/j.mce.2007.06.007 . hal-00531939

\section{HAL Id: hal-00531939 \\ https://hal.science/hal-00531939}

Submitted on 4 Nov 2010

HAL is a multi-disciplinary open access archive for the deposit and dissemination of scientific research documents, whether they are published or not. The documents may come from teaching and research institutions in France or abroad, or from public or private research centers.
L'archive ouverte pluridisciplinaire HAL, est destinée au dépôt et à la diffusion de documents scientifiques de niveau recherche, publiés ou non, émanant des établissements d'enseignement et de recherche français ou étrangers, des laboratoires publics ou privés. 


\section{Accepted Manuscript}

Title: Polymorphic variations in exon 10 of the Luteinizing Hormone Receptor: Functional consequences and associations with breast cancer

Authors: Djura Piersma, Miriam Verhoef-Post, Maxime P. Look, André G. Uitterlinden, Huibert A.P. Pols, Els M.J.J.

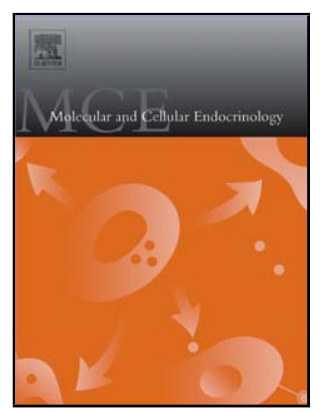

Berns, Axel P.N. Themmen

PII:

S0303-7207(07)00261-4

DOI: doi:10.1016/j.mce.2007.06.007

Reference: MCE 6682

To appear in: $\quad$ Molecular and Cellular Endocrinology

Received date: $\quad$ 19-12-2006

Revised date: 29-6-2007

Accepted date: $\quad 30-6-2007$

Please cite this article as: Piersma, D., Verhoef-Post, M., Look, M.P., Uitterlinden, A.G., Pols, H.A.P., Berns, E.M.J.J., Themmen, A.P.N., Polymorphic variations in exon 10 of the Luteinizing Hormone Receptor: Functional consequences and associations with breast cancer, Molecular and Cellular Endocrinology (2007), doi:10.1016/j.mce.2007.06.007

This is a PDF file of an unedited manuscript that has been accepted for publication. As a service to our customers we are providing this early version of the manuscript. The manuscript will undergo copyediting, typesetting, and review of the resulting proof before it is published in its final form. Please note that during the production process errors may be discovered which could affect the content, and all legal disclaimers that apply to the journal pertain. 
Polymorphic variations in exon 10 of the Luteinizing Hormone Receptor: Functional consequences and associations with breast cancer

Djura Piersma ${ }^{1}$, Miriam Verhoef-Post ${ }^{1}$, Maxime P Look ${ }^{2}$, André G. Uitterlinden ${ }^{1,3}$, Huibert A.P. Pols ${ }^{1,3}$, Els M.J.J. Berns ${ }^{2}$ and Axel P.N. Themmen ${ }^{1}$

${ }^{1}$ Departments of Internal Medicine,

${ }^{2}$ Medical Oncology and

${ }^{3}$ Epidemiology \& Biostatistics,

Erasmus MC, P.O. Box 2040, 3000 CA Rotterdam, The Netherlands

Correspondence to:

Axel P.N. Themmen

Department of Internal Medicine,

Erasmus MC - Room Ee532,

P.O. Box 2040, 3000 CA Rotterdam, The Netherlands

Phone: +31104087340 ,

Fax: +31104635430

Email: a.themmen@erasmusmc.nl

Running head: exon 10 LHR polymorphisms and breast cancer

Keywords: LH receptor, glycosylation, breast cancer, polymorphism 
ABSTRACT

Polymorphic variation of the LHR gene may affect receptor function and accordingly may influence ovarian steroid hormone action, including steroid hormonedependent clinical outcome.

The functional effects of two single nucleotide polymorphisms (SNPs), i.e. LHR 291Asn/Ser (rs12470652) and 312Ser/Asn (rs2293275) in the biologically interesting exon 10 of the LHR gene are described. Furthermore, ethnic diversity in allele frequencies and genotype distributions of both SNPs was determined. In addition associations with breast cancer were studied in 751 breast cancer patients.

In vitro transfection studies revealed altered glycosylation status and increased receptor sensitivity for the 291 Ser LHR variant. No functional consequences were observed for the 312SerAsn LHR SNP. The LHR 312Asn allele was slightly more often present in two independent breast cancer patient cohorts as compared to controls $(\mathrm{OR}=1.15 ; \mathrm{p}=0.03$ and $1.26 ; \mathrm{p}=0.001$, respectively $)$. In conclusion, although functional changes of the LHR 291Ser candidate allele were observed, no associations with breast cancer were found, while the LHR 312Asn allele can be regarded as a weak breast cancer risk allele. 


\section{INTRODUCTION}

The pituitary gonadotropin Luteinizing Hormone $(\mathrm{LH})$ is an essential regulator of ovarian steroid hormone synthesis in premenopausal women. By binding to the LH receptor (LHR), LH stimulates the production of androgens in the theca cells that surround growing follicles. Follicle Stimulating Hormone (FSH) subsequently regulates conversion of androgens to estrogens by the granulosa cell enzyme aromatase. In addition, LHR signaling has an essential role in reproduction through the transduction of the signal of the mid-cycle LH surge leading to ovulation and the subsequent maintenance of progesterone production by the corpus luteum. In case of pregnancy in humans, a second ligand for the LHR, i.e. human chorionic gonadotropin (hCG), takes over the role of sustaining progesterone synthesis by the corpus luteum. In human XY fetuses, hCG-induced LHR activity triggers male sex differentiation [1]. Clear evidence for the role of LH and LHR in humans in sex steroid hormone-dependent differentiation and reproduction has been obtained from observations in patients with inactivating mutations in LH $\beta$ (chromosome 19q13.33) and LHR (chromosome 2p21) genes. Interestingly, the extent of the functional consequences of various LHR mutations on LHR protein function in vitro are reflected in the severity of the phenotypic effects of the mutations in vivo $[2,3]$. More common polymorphic variation in the LHR gene may result in more subtle changes in receptor function, which over a lifetime period may have clinical consequences. Thus, the question arises whether slight changes in LHR activity such as those caused by polymorphisms have subtle effects on disease susceptibility, disease progression or response to treatment. So far, a total of 285 polymorphisms has 
been identified in the $\mathrm{LH}$ receptor gene at an average distance of approximately 300 base pairs (http://SNPper.chip.org; http://gvs.gs.washington.edu/GVS/). The majority of these polymorphisms are located in the large introns. Regarding the potential consequences of LHR gene variants for disease, we have recently shown clear associations between a polymorphic CTCCAG insertion in exon 1 of the LHR gene (rs4539842), which results in the insertion of two amino acids, Leu-Gln (insLQ), with characteristics and progression of breast cancer [4,5]. This polymorphism was clearly shown to improve receptor function [5].

The human LHR gene consists of 11 exons. Exon 1 encodes the signal peptide and the N-terminal cysteine-rich region. Exons 2 to 9 encode leucine-rich repeats involved in hormone binding. Exon 10 constitutes an important part of the so-called hinge region, more specifically, a part of the C-terminal cysteine-rich region which terminates the leucine-rich repast in many protiens. Exon 11 mainly encodes the transmembrane domain and the relatively small C-terminal intracellular domain. Interestingly, a deletion of exon 10 has been described in a patient with normal male sex differentiation, but delayed puberty, apparently because the del(exon10) LHR did not respond to $\mathrm{LH}$, while it was sensitive to hCG [6]. Indeed in vitro expression of the del(exon10) LHR showed a slightly decreased response to hCG whereas LH-induced receptor activation was severely impeded [7].

In addition to the LHR insLQ polymorphism, two specific single nucleotide polymorphisms (SNPs), leading to variable amino acids at positions 291 and 312 respectively: 291Asn/Ser (rs12470652) and 312Ser/Asn (rs2293275) are located in exon 
10, and may have subtle effects on LHR sensitivity for LH and hCG. The fact that the exon 10 291Asn/Ser and 312Ser/Asn SNPs are located at or near glycosylation sites increases this possibility, since glycosylation plays an important role in the G proteincoupled receptor superfamily for stability, trafficking and cell surface expression [8].

Growth and proliferation of both normal breast tissue and breast tumors is to a large extent dependent on estrogen, as reviewed in [9]. Amongst others, variability in estrogen exposure, possibly affected by polymorphic variation in genes involved in regulation of estrogen production and response, may explain differences in breast cancer presentation and outcome between individuals or populations [10-13]. Considering its role in the regulation of ovarian estrogen production, the LHR gene is a likely candidate gene contributing to possible inter-individual variability in estrogen exposure.

Furthermore, possible direct effects of LHR signaling on breast cancer development and progression cannot be excluded since LHR expression has been shown in breast cancer cell lines as well as in normal and malignant breast tissue $[14,15]$.

In this report we describe the potential effects of the 291Asn/Ser and 312Ser/Asn SNPs on LH receptor function. We have determined genotype frequencies in a large Caucasian cohort and smaller African-American and Chinese cohorts. In addition, association analyses with both SNPs were performed in 751 breast cancer patients with clinical follow-up. Notwithstanding the functional effects of substitution of 291Asn to Ser, no associations of the LHR 291Ser allele with risk, clinical presentation or outcome of breast cancer were observed, possibly due to the low LHR 291Ser allele frequency. However, the LHR 312Asn allele was identified as a risk allele for breast cancer. 


\section{MATERIALS AND METHODS}

\section{Transfection studies}

\section{Cell culture and transfection}

HEK293 cells were cultured in Dulbecco's modified Eagles's medium (DMEM)Ham's F-12, supplemented with $10 \%$ fetal calf serum containing penicillin and streptomycin. Transfection experiments concerning signal transduction and binding in HEK293 cells used a calciumphosphate transfection method as previously described [2]. The ectodomain-containing expression plasmids were transfected in HEK293 cells using the PolyFect transfection kit according to the manufacturer's instructions (Qiagen, Westburg, Leusden, The Netherlands).

\section{Construction of hLHR cDNA expression vectors}

The pSG5-hLHR-EGFP plasmid expressing the coding region of the hLHR extended with a 3'-hemagglutinin (HA1) immunotag and a 3'-EGFP (enhanced green fluorescent protein), carrying the CTCCAG insertion (insLQ) and Asn amino acids at positions 291 and 312 was used to construct full-length LH receptor expression plasmids $[16,17]$. Ectodomain expression plasmids (truncated after R365, amino acid numbering by taking the methionine start as number 1 and including the LQ insertion) were constructed from these plasmids by truncation as described previously [5]. Full-length and ectodomain pSG5-hLHR-EGFP plasmids were used to construct the 291Ser and 312Ser receptor constructs by site-directed mutagenesis (Quick Change ${ }^{\mathrm{TM}}$ site-directed 
mutagenesis kit, Stratagene, La Jolla, CA, USA), according to manufacturer's protocol. Primer sequence for changing 291Asn to 291Ser were:

CCAACAAAAGAACAGAGTTTTTCACATTCC (forward) and GGAAtGtGAAAAACtCTGtTCtTTtGTTGG (reverse). Primer sequences for changing 312Asn to312Ser were CAGTAAGGAAAGTGAGTAACAAAACAC (forward) and GTGTTTTGTTACTCACTTTCCTTACTG (reverse). Finally, all fulllength and ectodomain 291 and 312-LHR variants were subcloned into nonLQ-LHR expression plasmids (i.e. lacking the LQ insertion), as described previously [5].

\section{Analysis of signal transduction and cell surface expression}

Recombinant hCG and recombinant human LH were kindly provided by Organon (Oss, The Netherlands). In order to obtain dose response curves for hCG- and LHactivation of the cAMP-dependent luciferase reporter gene, subconfluent HEK293 cells were transiently transfected with $2 \mu \mathrm{g}$ of the cAMP-reporter plasmid pCRE 6 Lux [18], 2 $\mu \mathrm{g}$ SV40ß-galactosidase (transfection efficiency), $10 \mu \mathrm{g}$ of either pSG5-291Asn-312AsnhLHR-GFP pSG5-291Ser-312Asn-hLHR-GFP or pSG5-291Asn-312Ser-hLHR-GFP and

$6 \mu \mathrm{g}$ carrier DNA per $75 \mathrm{~cm}^{2}$. Two days after transfection, the cells were trypsinized and plated in 24-well tissue culture plates (Nunc, Roskilde, Denmark). The following day, cells were incubated for 6 hours in medium containing $0.1 \%$ BSA and increasing concentrations of hCG or LH. Cells were lysed and cAMP-dependent luciferase activity was measured as well as $\beta$-galactosidase activity as a control for transfection efficiency. Bmax and Kd (Scatchard analysis) were carried out as described previously [2,19]. 


\section{$L H$ receptor protein analysis}

HEK293 cells were transfected with different LHR-constructs for Western blot analyses of protein expression. In the deglycosylation experiments employing endoglycosidase $\mathrm{H}$ and $\mathrm{N}$-glycosidase F (PNGase F) ectodomain LHR expression plasmids were used as described in [5]. In brief, seventy-two hours after transfection, the cells were washed twice in Phosphate Buffered Saline (PBS) and collected in PBS, 20 mM N-ethylmaleimide, with 1x protease inhibitor cocktail (Sigma-Aldrich, Zwijndrecht, The Netherlands) and centrifuged for $1 \mathrm{~min}$ at $2000 \mathrm{rpm}$. Immediately after pelleting, cells were snap frozen in liquid nitrogen and stored at $-80 \mathrm{C}$ before analysis. Cell pellets were resuspended in Laemmli sample buffer to a final concentration of $1 \mu \mathrm{g} / \mu \mathrm{l}$ and disrupted by 10 passages through a 23-gauge needle. Finally, samples were denatured at $95 \mathrm{C}$ for $5 \mathrm{~min}$ and analyzed by gel electrophoresis and Western blotting using a conjugated HA1-horseradish peroxidase rat monoclonal antibody (Roche Diagnostics Nederland BV, Almere, The Netherlands) at 1:5000 dilution.

\section{Study populations and subjects}

\section{Breast tumor samples}

Genotype analysis and analyses of (disease free) survival and clinico-pathological features were performed in 751 retrospectively collected patients of whom detailed follow-up is currently available, as described previously [5]. In brief, $38 \%$ of patients was premenopausal, $62 \%$ postmenopausal. Data on lymph node status showed that $43 \%$ was node negative and 57\% node positive. Tumor size distribution was 36\% T1, 52\% T2 and 
$12 \%$ T3/4. Tumors showed $76 \%$ estrogen receptor expression vs. $24 \%$ no expression and $67 \%$ showed progesterone receptor expression vs. $28 \%$ no expression and $5 \%$ was unknown (cut-off value: $10 \mathrm{fmol} / \mathrm{mg}$ protein). $75 \%$ of the patients did not receive any adjuvant therapy, while $6 \%$ had received hormonal therapy, $17 \%$ chemotherapy and $1 \%$ both. Median age in these breast cancer patients is 57 (range: 22-90) year, the median follow-up period from primary surgery is 129 months (range: 13-255 months). For the comparison of LHR 312Asn allele frequencies, a second series 594 patients was selected from the database of the Department of Medical Oncology of the Erasmus MC in Rotterdam, The Netherlands. Of these patients clinical follow-up data were not complete at the time of inclusion in our studies. The median age: 63 years (range: $23-90, n=521$ ). The breast cancer patients included in all studies were mainly form the ethnically homogeneous Caucasian population in the South-Western part of The Netherlands. The study design of the breast cancer cohorts was approved by the Medical Ethics Committee of the Erasmus MC, Rotterdam, The Netherlands.

\section{Eindhoven Perimenopausal Osteoporosis Study (EPOS)}

The EPOS study is a population-based cohort study of pre-, peri- and postmenopausal Caucasian women born between 1941 and 1947, living in the city of Eindhoven, The Netherlands (median age 50.0 (range: 46-57) years). Rationale and design have been described previously [20]. Study design was approved by the Medical Ethics Committee of the Erasmus MC. For the present study, 22 women who reported a history of surgery for (suspected) breast carcinoma, were excluded and genotyping was performed on 1806 subjects. 


\section{Rotterdam Study}

As a control cohort we also studied 3794 non-case women of the Rotterdam Study, a prospective population based cohort study of 6155 individuals aged 55 years and over. Breast cancer cases were identified as described previously [21]. Rationale and design have been described previously [22]. The Rotterdam Study was approved by the Medical Ethics Committee of the Erasmus MC.

\section{African-American and Chinese subjects}

Genotype analyses were conducted in anonimized individuals with self-described ethnic heritage from the Human Variation panel obtained from Coriell Cell Repositories (Coriell Institute, Camden, NJ, USA). Subjects included 110 (Han-)Chinese, (55 male and 55 female) and 60 African-American (14 male and 46 female).

\section{Genotype analyses}

High molecular weight genomic DNA was used as template for PCR amplification. The 291Asn/Ser and 312Ser/Asn-LHR polymorphisms were determined using the Taqman allelic discrimination assay. Primer sequences used for amplification of the fragment of exon 10 including the 291Asn/Ser SNP were CTGAAGTCCAAAAGCTCAAATGCT (forward) and TGTGCTTTCACATTGTTTGGAAAAGT (reverse). Used probes (with SNP underlined) were 5'-VIC-CAGACAGAㅁTTTTTC (sense) and 5'-FAM- CAGACAGA $\underline{\text { TTTTTTC }}$ (sense). For detection of the $312 \mathrm{Ser} / \mathrm{Asn} \mathrm{SNP}$, used primer sequences were 
TTTTCCAAACAATGTGAAAGCACAGT (forward) and GATACGACTTCTGAGTTTCCTTGCA (reverse) and probes 5'-VICTTACAGTGTTTTGTTATTCACTT (anti-sense) and 5'-FAMCAGTGTTTTGTTAㅡTCACTT (anti-sense). Primer and probe sequences were optimized using the SNP assay-by-design service of Applied Biosystems, Perkin Elmer, Nieuwerkerk aan den IJssel, The Netherlands), for details see http://store.appliedbiosystems.com. Reactions were performed on the Taqman Prism 7900HT 384 wells format. Primary breast cancer specimens, flash-frozen and stored in liquid-nitrogen contain a relatively high proportion of non-tumor tissue. This ensures accurate genotyping, irrespective of the possible loss of heterozygosity (LOH) that may occur in tumor tissue, since enough DNA from non-tumor tissue will contribute to the final result [4]. Furthermore, we have examined Hardy-Weinberg equilibrium to test for possible LOH.

\section{Statistical analysis}

Mean values of in vitro transfection studies were compared by one way analysis of variance (ANOVA), EC50 values were log-transformed prior to analysis. Pearson's $\chi^{2}$ analysis was used to test for independence of the alleles (Hardy-Weinberg equilibrium, HWE) and to compare genotype distributions in breast cancer patients and control populations. Odds ratios were computed to compare allele frequencies between breast cancer patients and EPOS controls. Associations between the various patient and tumor characteristics and the LHR 291Asn/Ser and 312Ser/Asn genotypes were investigated using Pearson's $\chi^{2}$ and Fisher's exact test where appropriate. Uni- and multivariate 
overall (endpoint: death) and disease free (endpoint: recurrence including second primary breast tumor) survival analyses were carried out using proportional hazards regression analysis. The assumption of proportional hazards was investigated using a test based on the Schoenfeld residuals [23] and was not violated for LHR 291Asn/Ser and 312Ser/Asn genotypes. Differences between HRs per LHR 291Asn/Ser and 312Ser/Asn genotype were tested using the likelihood ratio test associated with the Cox regression analysis. Disease free and overall survival probabilities were calculated using the actuarial method of Kaplan-Meier [24]. Survival probabilities were compared across LHR 291Asn/Ser and 312Ser/Asn genotypes using the log-rank tests for equality of survival functions. All computations were carried out using the STATA statistical package, version 9.2 (Stata Corp., College Station, TX, USA). Statistical significance was assumed at $\mathrm{p} \leq 0.05$, $\mathrm{p}$ values are two-tailed and relate to data during the total period of follow-up. 


\section{RESULTS}

\section{$291 S$ affects LHR protein function and expression}

Possible effects of the LHR polymorphisms on cell surface expression, hCG ligand binding and hCG-dependent LHR signal transduction in vitro were investigated in transfected HEK293 cells. For the comparison of effects of 291Ser vs. 291Asn and 312Ser vs. 312Asn we used functionally neutral nonLQ constructs (i.e. lacking the LQ insertion in the signal sequence which increases LHR sensitivity and expression [5]). Moreover, the nonLQ-LHR allele is the most frequent variant in the Caucasian population and therefore the most relevant. The insLQ polymorphism is over 30.000 base pairs distant from the exon 10 SNPs. Analysis of genotype data using Haploview [25,26] indicated no linkage between the exon 10 SNPs and the insLQ polymorphism, while the maximum D' (a measure of linkage disequilibrium) in breast cancer and EPOS cohorts is 0.25 with a maximum $r^{2}$ of 0.03 between the insLQ polymorphism in the signal sequence and the 312Ser/Asn SNP in exon 10.

The effects of the amino acid substitutions at positions 291 and 312 were tested comparing three constructs: 291Asn-312Asn-LHR, 291Ser-312Asn-LHR and 291Asn312Ser-LHR. The hypothetical 291Ser-312Ser-LHR variant was not considered in the transfection studies since our own data and the data from public SNP databases show that this LHR variant is non-existent in the population. In cells expressing the $291 \mathrm{Ser}-$ 312Asn-LHR construct, the potency of hCG as represented by the EC50 value, was increased two-fold compared to 291Asn-312Asn-LHR and 291Asn-312Ser-LHR expressing cells ( $\mathrm{p}=0.001 \mathrm{~N}=3-5$; Table 1 and Figure 1). Similar results were obtained 
with LH (results not shown). Subsequently we determined cell surface expression of cells expressing either one of these constructs by $\left[{ }^{125} \mathrm{I}\right]-\mathrm{hCG}$ saturation binding. The Bmax of 291Ser-312Asn-LHR expressing HEK293 cells was not different from 291Asn-312AsnLHR and 291Asn-312Ser-LHR expressing cells ( $p=0.69$; Table 1). The Kd values for all three LHR constructs from Scatchard analyses were not different (Table 1).

The Asn (N) at position 291 constitutes a consensus site for $\mathrm{N}$-linked glycosylation: 291N-292F-293S. Presence of carbohydrate chains was shown by deglycosylation with PNGase F (Figure 2A) and endoglycosidase H (not shown) employing truncated LH receptor ectodomain constructs. Substitution of 291Asn by Ser, removing the glycosylation site, results in increased electrophoretic mobility of both truncated (Figure 2B) and full-length (Figure 2C) LH receptor proteins, indicating a change in glycosylation status at 291 . The $312 \mathrm{Ser} / \mathrm{Asn}$ polymorphism is located one amino acid prior to a potential N-linked glycosylation site: $313 \mathrm{~N}-314 \mathrm{~K}-315 \mathrm{~T}$. As expected, the amino acid change of Ser to Asn at position 312 did not affect the glycosylation at 313Asn (313N) (results not shown).

\section{Allele frequencies and genotype distributions}

The 291Asn/Ser and 312Ser/Asn genotypes were determined in 751 breast cancer patients and in 5600 Caucasian (two separate control groups: EPOS and the Rotterdam Study), 110 Chinese and 60 African-American controls. Two control groups were included in the analysis since we do not have access to a group of control women with similar age distribution. Therefore we decided to analyze a group with younger women (EPOS; median age 49.5 years) and a group of older women (Rotterdam Study; median 
age 70.8 years). Hardy Weinberg equilibrium conditions were met in in all cohorts, except in the control women from the Rotterdam Study (Table 2). We feel that this deviation is due to chance, since we performed ten HWE tests in this study. In addition, the Rotterdam Study represents a stable ethnically homogeneous population and the observed LHR 291Ser allele frequency is similar to that in other Caucasian populations, including data available in internet databases (http://SNPper.chip.org; http:/gvs.gs.washington.edu/GVS/).

The minor LHR 291Ser allele has a low frequency ranging from virtually absent in the Chinese and African-American subjects to $6 \%$ in Caucasian subjects (Table 2). The minor LHR 312Asn allele showed wide variety in frequency and genotype distribution with an allele frequency ranging from $7 \%$ to $72 \%$ in the small Chinese and AfricanAmerican cohorts, respectively (Table 2).

291Asn/Ser and 312Ser/Asn LHR genotype and breast cancer risk

Genotype distributions for the 291Asn/Ser SNP and 312Ser/Asn SNPs were compared between breast cancer patients and the Caucasian control women. The 291Asn/Ser genotype distributions were similar in all Caucasian cohorts $(p=0.19$; Table 2).

Interestingly, the LHR 312Asn genotype was observed more frequently in breast cancer patients compared to EPOS controls resulting in an odds ratio (OR) of presence of the LHR 312Asn allele of $1.15(\mathrm{OR}=1.15 ; 95 \%$ CI 1.02-1.30; $\mathrm{p}=0.03)$. To validate this finding, we determined the LHR 312Asn allele frequency in an independent set of 594 breast cancer patients. In this validation set an increased LHR 312Asn allele frequency 
compared to the EPOS controls was also observed (OR=1.26; $95 \%$ CI 1.10-1.43; $\mathrm{p}=0.001$ ). Similar results were obtained when comparing all breast cancer patients with the Rotterdam Study control women (OR=1.11 (1.01-1.2); $\mathrm{p}=0.03$; Table 3).

\section{LHR 291Ser and 312Ser/Asn LHR genotype and breast cancer clinico-pathological} features and survival

Previously we have shown that another LHR variant, insLQ-LHR, causes increased LH receptor function and is associated with increased tumor size and poor breast cancer outcome [5]. Thus, based on the stimulatory effects of the 291Ser-LHR variant on receptor sensitivity, this allele was chosen for association analyses in breast cancer patients. Because less than $1 \%$ of the patients were homozygous for the LHR 291Ser allele, heterozygous and homozygous carriers of LHR 291Ser allele were combined in the association analyses for sufficient statistical power. Based on the observation that the LHR 312Asn allele was present more frequently in breast cancer patients compared to EPOS controls, differences in patient and tumor characteristics were investigated for this SNP as well.

The LHR 291Ser allele appeared to be differently distributed across the tumor size categories, but the difference was not significant $(\mathrm{p}=0.06)$. Furthermore this association was not linear across the successive tumor size categories ( $\mathrm{p}$-trend $=0.12$ ), suggesting absence of a causal association. Furthermore the LHR 291Ser allele appeared to be associated with progesterone receptor expression (cut-off value $>10 \mathrm{fmol} / \mathrm{mg}$ protein), but this was not significant $(\mathrm{p}=0.11)$. The LHR 312Asn allele frequency was slightly higher in the youngest age category ( $<40$ years of age) as compared to patients 
aged 40 years and older ( 0.50 vs. 0.44$)$, but this difference was not significant $(\mathrm{p}=0.17)$. Both exon 10 SNPs did not show associations with any other patient or tumor characteristics, i.e. menopausal status, nodal involvement, histological grade, estrogen receptor status, history of adjuvant therapy or overall and disease free survival (data not shown). 


\section{DISCUSSION}

In the current report we present the results of a study of the functional effects, the genotype distribution, and the association with clinico-pathological characteristics and disease outcome of two potentially functional, closely spaced single nucleotide polymorphisms (SNPs) 291Asn/Ser (rs 12470652) and 312Ser/Asn (rs2293275) in exon 10 the LHR gene.

Our results indicate that 291Asn in the LH receptor is glycosylated, confirming the data on the pig LH receptor, where it was shown that $36 \%$ of all glycan residues in the mature receptor were found at the homologous 291 position (Vu-Hai et al. 2000). The absence of glycan side chains at this position in the 291Ser variant causes a slight decrease in the EC50 of the LH receptor, whereas binding studies, western analysis and signal transduction experiments show that expression levels of both $\mathrm{LH}$ receptor variants are comparable. Furthermore, ligand affinity does not seem to be affected as indicated by the absence of a change in the $\mathrm{Kd}$. These results indicate that Asn or Ser at position 291 is involved in the relay of the signal of binding of the hormone to the signal transducing transmembrane domain, rather than binding of the ligand per se. Ser at position 277 has been shown to interact with amino acid residues in the second extracellular loop of the LH receptor, showing that this domain of the $\mathrm{LH}$ receptor is positioned close enough to allow such interactions [27]. Thus, the absence of a glycan side chain at position 291, may facilitate interaction of the hormone-bound ectodomain with the transmembrane domain of the LH receptor. Changing 291Asn to Ser affects the response of the LH 
receptor to both ligands. This is not the case when exon 10 is deleted completely, as has been observed in a single patient and in new world monkeys [6,7].

The presence of an Asn or Ser residue at position 312 did not affect binding or signal transduction in vitro at all. It will be interesting to see whether the glycosylation status of the receptor can partially explain the effect of the deletion of exon 10 , or that other functions of this 27 amino acid stretch are involved.

The LHR 291Asn/Ser and 312Ser/Asn SNPs result from an A/G change at nucleotide 872 and 935, respectively. The observed frequencies for both alleles in this study were in accordance with the reported frequencies for both SNPs (http://SNPper.chip.org; http://gvs.gs.washington.edu/GVS/). The closely spaced SNPs are highly linked, but poorly correlated $\left(\mathrm{r}^{2}=0.05\right)$ due to different minor allele frequencies. Genetic variation in allele frequencies between ethnic groups may widely vary and may affect disease-related outcomes (reviewed in $[28,29])$. In the present study three different ethnic groups, i.e. Caucasians, Chinese and African-American subjects, were included in genotype analyses. Although the sample size of the ethnic cohorts in the present study are rather small, the results nicely corroborate the results as they are found in the web-based databases (http://gvs.gs.washington.edu/GVS/). Interestingly, the LHR 291Ser allele is virtually absent in the Chinese and African-American subjects, suggesting that the LHR 291Asn/Ser SNP represents a relatively recent Caucasian mutation. The frequency of the LHR 312Asn allele also varies widely, from $72 \%$ in African-Americans to $7 \%$ in Chinese with an intermediate frequency in the Caucasian women (40-44\%). Prevalence, clinical presentation and outcome of breast cancer differ between different ethnic groups [13,30,31]. Breast cancer incidence is much lower in 
Chinese women as compared to Caucasian women [32]. African-American women show a lower incidence as compared to Caucasian women, but this changes after menopause. Furthermore, they have much higher overall mortality [33]. However, conclusions concerning the ethnic diversity in frequency of the LHR variants and the occurrence or clinical phenotype of breast cancer in ethnic groups has to await much more detailed studies using larger ethnically diverse breast cancer cohorts.

Interestingly, the LHR 312Asn allele constitutes a risk allele for breast cancer since it was more often observed in two independent sets of breast cancer patients (i.e. 721 patients and 594 patients, respectively, mainly from the South-Western part of the Netherlands, as compared to 1776 Caucasian EPOS controls. This results in a moderate, but statistically significant, increased risk of breast cancer (OR=1.15 (95\% CI 1.02-1.30); $\mathrm{p}=0.03)$ and $(\mathrm{OR}=1.25(95 \% \mathrm{CI} 1.10-1.43) ; \mathrm{p}=0.001)$ respectively. This results could be replicated when comparing all breast cancer patients with a second, older, control group from the Rotterdam Study $(\mathrm{OR}=1.11(1.01-1.2) ; \mathrm{p}=0.03)$. Interestingly, the effect size is similar to the increased breast cancer risk following ever use vs. never use of oral contraceptives [34]. Furthermore, the trend that was observed of a lower LHR 312Asn allele in the oldest patient categories may support the suggestion that LHR 312Asn is a risk allele. However, these results need to be validated in independent studies. No significant associations of the 312Ser/Asn SNP with clinico-pathological characteristics or outcome were observed. Since we did not observe functional effects of the 312Asn LHR variant in our transfection studies, linkage with another, perhaps still unknown, functional SNP that drives the association cannot be excluded. Linkage analysis in Haploview, using a minimum $r^{2}$ of 0.8 , shows linkage of the $312 \mathrm{Ser} / \mathrm{Asn}$ SNP to 
rs11125179, a silent SNP (355Asp/Asp) in exon 11 near the intron/exon boundary, as well as linkage to two intron SNPs: rs2349101 and rs17326251 about 1000 bp upstream of exons 10 and 11 respectively. One of these SNPs may affect protein expression or function, possibly through mRNA production or stability [35].

The absence of an association with any of the patient and tumor characteristics or with overall or disease free survival was unexpected in view of the increased sensitivity of the 291Ser LHR protein in vitro. This is most likely caused by insufficient power to detect an in vivo effect in view of the very low LHR 291Ser allele frequency. Compensatory adjustments of LH production in the hypothalamic-pituitary-ovarian axis in premenopausal life masking a subtle functional effect of the polymorphism cannot be excluded either

In conclusion, we have shown that the 291 Ser LHR variant results in increased LHR sensitivity, but the presence of a 291Ser LHR allele was not associated with any breast cancer patient characteristic. Interestingly, when comparing breast cancer patients vs. non-case controls, a slightly increased LHR 312Asn allele frequency was observed in breast cancer patients. These results suggest that, either or not via linkage with a functional polymorphism, the LHR 312Asn allele may be a risk allele for breast cancer development. This needs to be validated in a large case control study. 


\section{Acknowledgements}

The authors wish to thank Lisette Stolk, Marianna A. Timmerman, Chantal Goudswaard and Anke van Kerkwijk for technical support and drs. Martijn B. Bruysters and Fernando Rivadeneira for constructive discussions. 


\section{References}

[1] Themmen, A.P.N. and Huhtaniemi, I.T. (2000) Mutations of gonadotropins and gonadotropin receptors: elucidating the physiology and pathophysiology of pituitary-gonadal function. Endocr Rev 21, 551-83.

[2] Martens, J.W.M., Verhoef-Post, M., Abelin, N., Ezabella, M., Toledo, S.P., Brunner, H.G. and Themmen, A.P.N. (1998) A homozygous mutation in the luteinizing hormone receptor causes partial Leydig cell hypoplasia: correlation between receptor activity and phenotype. Mol Endocrinol 12, 775-84.

[3] Piersma, D., Verhoef-Post, M., Berns, E.M. and Themmen, A.P. (2007) LH receptor gene mutations and polymorphisms: An overview. Mol Cell Endocrinol 260-262, 282-6.

[4] Powell, B.L., Piersma, D., Kevenaar, M.E., van Staveren, I.L., Themmen, A.P.N., Iacopetta, B.J. and Berns, E.M.J.J. (2003) Luteinizing hormone signaling and breast cancer: polymorphisms and age of onset. J Clin Endocrinol Metab 88, 1653-7.

[5] Piersma, D., Berns, E.M.J.J., Verhoef-Post, M., Uitterlinden, A.G., Braakman, I., Pols, H.A.P. and Themmen, A.P.N. (2006) A common polymorphism renders the luteinizing hormone receptor protein more active by improving signal peptide function and predicts adverse outcome in breast cancer patients. J Clin Endocrinol Metab 91, 1470-6.

[6] Gromoll, J., Gudermann, T., Greshniok, A., Nieschlag, E. and Seif, F.J. (1999) Male pseudohermaphroditism due to an inactivating mutation in the extracellular domain of the luteinizing hormone receptor. Exp. Clinic. Endocrin. Diab. 107.

[7] Muller, T., Gromoll, J. and Simoni, M. (2003) Absence of exon 10 of the human luteinizing hormone $(\mathrm{LH})$ receptor impairs $\mathrm{LH}$, but not human chorionic gonadotropin action. J Clin Endocrinol Metab 88, 2242-9.

[8] Saito, Y., Tetsuka, M., Yue, L., Kawamura, Y. and Maruyama, K. (2003) Functional role of N-linked glycosylation on the rat melanin-concentrating hormone receptor 1. FEBS Lett 533, 29-34.

[9] Clarke, R.B. (2006) Ovarian steroids and the human breast: Regulation of stem cells and cell proliferation. Maturitas 54, 327-34.

[10] Martin, A.M. and Weber, B.L. (2000) Genetic and hormonal risk factors in breast cancer. J Natl Cancer Inst 92, 1126-35.

[11] Mitrunen, K. and Hirvonen, A. (2003) Molecular epidemiology of sporadic breast cancer. The role of polymorphic genes involved in oestrogen biosynthesis and metabolism. Mutat Res 544, 9-41.

[12] Windham, G.C., Elkin, E., Fenster, L., Waller, K., Anderson, M., Mitchell, P.R., Lasley, B. and Swan, S.H. (2002) Ovarian hormones in premenopausal women: variation by demographic, reproductive and menstrual cycle characteristics. Epidemiology 13, 675-84.

[13] Swanson, G., Haslam, S.Z. and Azzouz, F. (2003) Breast cancer among young African-American women: a summary of data and literature and of issues discussed during the Summit Meeting on Breast Cancer Among African American Women, Washington, DC, September 8-10, 2000. Cancer 97, 273-9. 
[14] Meduri, G., Charnaux, N., Loosfelt, H., Jolivet, A., Spyratos, F., Brailly, S. and Milgrom, E. (1997) Luteinizing hormone/human chorionic gonadotropin receptors in breast cancer. Cancer Res 57, 857-64.

[15] Meduri, G., Charnaux, N., Spyratos, F., Hacene, K., Loosfelt, H. and Milgrom, E. (2003) Luteinizing hormone receptor status and clinical, pathologic, and prognostic features in patients with breast carcinomas. Cancer 97, 1810-6.

[16] Martens, J.W.M., Lumbroso, S., Verhoef-Post, M., Georget, V., Richter-Unruh, A., Szarras-Czapnik, M., Romer, T.E., Brunner, H.G., Themmen, A.P.N. and Sultan, C. (2002) Mutant luteinizing hormone receptors in a compound heterozygous patient with complete Leydig cell hypoplasia: abnormal processing causes signaling deficiency. J Clin Endocrinol Metab 87, 2506-13.

[17] Kraaij, R., Post, M., Kremer, H., Milgrom, E., Epping, W., Brunner, H.G., Grootegoed, J.A. and Themmen, A.P.N. (1995) A missense mutation in the second transmembrane segment of the luteinizing hormone receptor causes familial male-limited precocious puberty. J Clin Endocrinol Metab 80, 3168-72.

[18] Himmler, A., Stratowa, C. and Czernilofsky, A.P. (1993) Functional testing of human dopamine D1 and D5 receptors expressed in stable cAMP-responsive luciferase reporter cell lines. J Recept Res 13, 79-94.

[19] Fanelli, F., Verhoef-Post, M., Timmerman, M., Zeilemaker, A., Martens, J.W.M. and Themmen, A.P.N. (2004) Insight into mutation-induced activation of the luteinizing hormone receptor: molecular simulations predict the functional behavior of engineered mutants at M398. Mol Endocrinol 18, 1499-508.

[20] Smeets-Goevaers, C.G., Lesusink, G.L., Papapoulos, S.E., Maartens, L.W., Keyzer, J.J., Weerdenburg, J.P., Beijers, L.M., Zwinderman, A.H., Knottnerus, J.A., Pols, H.A. and Pop, V.J. (1998) The prevalence of low bone mineral density in Dutch perimenopausal women: the Eindhoven perimenopausal osteoporosis study. Osteoporos Int 8, 404-9.

[21] González-Zuloeta Ladd, A.M., Vasquez, A.A., Siemes, C., Yazdanpanah, M., Coebergh, J.W., Hofman, A., Stricker, B.H. and van Duijn, C.M. (2006) Differential Roles of Angiotensinogen and Angiotensin Receptor type 1 Polymorphisms in Breast Cancer Risk. Breast Cancer Res Treat.

[22] Hofman, A., Grobbee, D.E., de Jong, P.T. and van den Ouweland, F.A. (1991) Determinants of disease and disability in the elderly: the Rotterdam Elderly Study. Eur J Epidemiol 7, 403-22.

[23] Grambsch, P.M. and Therneau, T.M. (1994) Proportional hazards tests and diagnostics based on weighted residuals. Biometrika 81, 515-26.

[24] Kaplan, E.M. and Meier, P. (1958) Nonparametric estimation from incomplete observations. J Am Stat Assoc 53, 457-481.

[25] Barrett, J.C., Fry, B., Maller, J. and Daly, M.J. (2005) Haploview: analysis and visualization of LD and haplotype maps. Bioinformatics 21, 263-5.

[26] (2003) The International HapMap Project. Nature 426, 789-96.

[27] Nakabayashi, K., Kudo, M., Kobilka, B. and Hsueh, A.J. (2000) Activation of the luteinizing hormone receptor following substitution of Ser-277 with selective hydrophobic residues in the ectodomain hinge region. J Biol Chem 275, 3026471. 
[28] Ademuyiwa, F.O. and Olopade, O.I. (2003) Racial differences in genetic factors associated with breast cancer. Cancer Metastasis Rev 22, 47-53.

[29] Chowbay, B., Zhou, S. and Lee, E.J. (2005) An interethnic comparison of polymorphisms of the genes encoding drug-metabolizing enzymes and drug transporters: experience in Singapore. Drug Metab Rev 37, 327-78.

[30] Bondy, M.L. and Newman, L.A. (2003) Breast cancer risk assessment models: applicability to African-American women. Cancer 97, 230-5.

[31] Hunter, C.P. (2000) Epidemiology, stage at diagnosis, and tumor biology of breast carcinoma in multiracial and multiethnic populations. Cancer 88, 1193-202.

[32] Key, T.J., Verkasalo, P.K. and Banks, E. (2001) Epidemiology of breast cancer. Lancet Oncol 2, 133-40.

[33] Newman, L.A. (2005) Breast cancer in African-American women. Oncologist 10, $1-14$.

[34] Kahlenborn, C., Modugno, F., Potter, D.M. and Severs, W.B. (2006) Oral contraceptive use as a risk factor for premenopausal breast cancer: a metaanalysis. Mayo Clin Proc 81, 1290-302.

[35] Tabor, H.K., Risch, N.J. and Myers, R.M. (2002) Opinion: Candidate-gene approaches for studying complex genetic traits: practical considerations. Nat Rev Genet 3, 391-7. 


\section{LEGENDS}

Figure 1

291Ser-312Asn-LHR is more sensitive to hCG. hCG-induced cAMP response element activation was compared between 291Ser-312Asn (closed squares), 291Asn-312Asn (open circles) and 291Asn-312Ser (open triangles) -LHR variants. HEK293 cells were transfected with the respective expression plasmids in the presence of cAMP-reporter plasmid $\mathrm{pCRE}_{6}$ Lux and SV40ß-galactosidase (transfection efficiency). Subsequently, the cells were incubated for $6 \mathrm{~h}$ with different concentrations of hCG and luciferase activity was measured.

\section{Figure 2}

Changing 291Asn to Ser affects glycosylation of the LHR. A. HEK293 cells were transfected with respective ectodomain expression plasmids, whole cell lysates were treated with PNGaseF and subsequently separated using $10 \%$ polyacrylamide gels and analyzed by Western blotting with an HA1 antibody. The left and right lanes contain LHR protein before and after PNGaseF treatment, respectively. The numbers on the left indicate apparent molecular mass of protein size markers. After deglycoslyation treatment, the larger band (indicated by upper arrow on right-hand side) of around 51 $\mathrm{kDa}$ changes mobility to an apparent molecular mass of around $43 \mathrm{kDa}$ (indicated by lower arrow on right-hand side), indicating that the $51 \mathrm{kDa}$ band is glycosylated. $\mathrm{B}$ and C. HEK293 cells transfected with 291Ser LHR constructs (right lane) show increased electrophoretic mobility as compared to 291Asn LHR construct (left lane) by Western 
blot analysis, both in ectodomain LHR-constructs (B) and in full-length constructs (C; middle lane contains untransfected cells), indicating a decrease of glycan residues. 


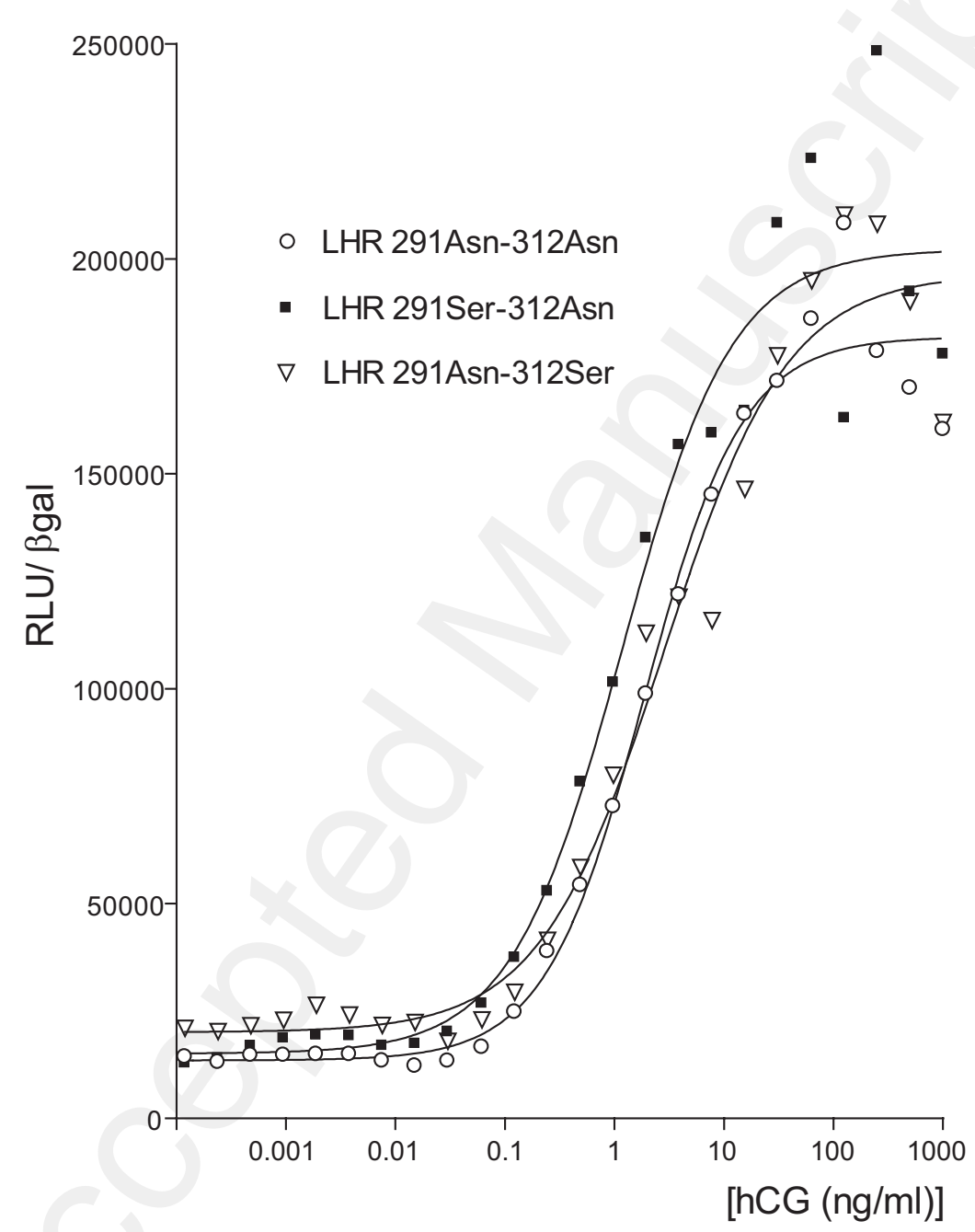


Table 1. Functional analyses of 291Asn/Ser and 312Ser/Asn LHR variants in HEK293 transfected cells.

\begin{tabular}{|c|c|c|c|c|c|}
\hline LHR construct & $\begin{array}{c}\text { EC50 }(\text { mean } \pm \text { sd) } \\
{[\mathrm{pM} \mathrm{hCG}]}\end{array}$ & $\mathrm{n}$ & $\begin{array}{c}\text { Bmax }(\text { mean } \pm \mathrm{sd}) \\
{[\mathrm{fmol} / \mathrm{mg} \text { protein }]}\end{array}$ & $\mathrm{n}$ & $\mathrm{Kd} \pm$ error $[\mathrm{nM}]$ \\
\hline 291Asn-312Asn & $61.9 \pm 13.6$ & 5 & $48.2 \pm 11.8$ & 10 & $3.77 \pm 0.96$ \\
\hline 291Asn-312Ser & $64.7 \pm 9.3$ & 3 & $56.1 \pm 16.4$ & 10 & $2.16 \pm 0.16$ \\
\hline 291Ser-312Asn & $29.3 \pm 2.4^{* * *}$ & 3 & $59.2 \pm 11.6$ & 10 & $5.67 \pm 0.44$ \\
\hline
\end{tabular}

EC50 values are determined by CRE receptor assay, Bmax values by radioligand binding assay and Kd value from one Scatchard analysis; ${ }^{* * *} \mathrm{p}=0.001$ 
Table 2. Allele frequencies and genotype distributions for breast cancer patients and non-case cohorts

\begin{tabular}{|c|c|c|c|c|c|}
\hline & \multicolumn{3}{|c|}{ Caucasian } & Chinese & $\begin{array}{l}\text { African- } \\
\text { American }\end{array}$ \\
\hline & Breast cancer & \multicolumn{4}{|c|}{ Control populations } \\
\hline & & EPOS & Rotterdam & & \\
\hline Total number ${ }^{\mathrm{a}}$ & 751 & 1806 & 3794 & 110 & 60 \\
\hline Assessment period & $1978-1990$ & 1994-1995 & 1990-1993 & 7 & \\
\hline \multicolumn{6}{|l|}{ LHR 291Asn/Ser } \\
\hline Allele frequency ${ }^{\mathrm{c}}$ & 0.05 & 0.06 & 0.06 & 0.00 & 0.01 \\
\hline 291Asn/291Asn (\%) & $673(89.6)$ & $1580(89.0)$ & $3169(89.2)$ & $108(100)$ & $55(98.2)$ \\
\hline 291Asn/291Ser (\%) & $76(10.1)$ & $190(10.7)$ & $363(10.2)$ & 0 & $1(1.8)$ \\
\hline 291Ser/291Ser (\%) & $2(0.3)$ & $6(0.3)$ & $19(0.5)$ & 0 & 0 \\
\hline HWE $(p)^{d}$ & 0.92 & 0.91 & 0.02 & 1.0 & 0.95 \\
\hline \multicolumn{6}{|l|}{ LHR 312Ser/Asn } \\
\hline Allele frequency ${ }^{c}$ & 0.44 & 0.40 & 0.42 & 0.07 & 0.72 \\
\hline 312Ser/312Ser $(\%)$ & $229(31.8)$ & $628(35.4)$ & $1269(33.4)$ & $95(87.2)$ & $7(12.3)$ \\
\hline 312Ser/312Asn (\%) & $353(49.0)$ & $862(48.5)$ & $1840(48.5)$ & $13(11.9)$ & $19(33.3)$ \\
\hline 312Asn/312Asn (\%) & $139(19.3)$ & $286(16.1)$ & $685(14.2)$ & $1(0.9)$ & $31(54.4)$ \\
\hline $\operatorname{HWE}(\mathrm{p})^{\mathrm{d}}$ & 0.89 & 0.73 & 0.69 & 0.47 & 0.15 \\
\hline
\end{tabular}

${ }^{a}$ Numbers in cells may not add up due to incomplete genotyping

${ }^{\mathrm{b}}$ Median age at assessment in years

${ }^{\mathrm{c}}$ Frequency of the minor allele is shown

${ }^{\mathrm{d}}$ Hardy-Weinberg equilibrium 
Table 3. Odds of LHR 291Ser and LHR 312Asn alleles in Breast cancer patients vs. Caucasian control cohorts

\begin{tabular}{|c|c|c|c|}
\hline & \multirow[t]{2}{*}{ Breast cancer } & \multicolumn{2}{|c|}{ Caucasian controls } \\
\hline & & EPOS & Rotterdam Study \\
\hline Total number of alleles ${ }^{\mathrm{a}}$ & 2690 & 3612 & 7588 \\
\hline & & & \\
\hline Median age $^{\mathrm{b}}$ & 60.4 & 49.5 & 70.8 \\
\hline LHR 291Asn allele & $2458(95.3)$ & $3350(94.3)$ & $6701(94.4)$ \\
\hline LHR 291Ser allele & $122(4.7)$ & $202(5.7)$ & $401(5.6)$ \\
\hline \multicolumn{2}{|c|}{ OR LHR 291Ser } & $\mathrm{p}=\mathrm{n} . \mathrm{s}$. & $\mathrm{p}=\mathrm{n} . \mathrm{s}$. \\
\hline LHR 312Ser allele & $1453(55.2)$ & $2118(59.6)$ & $4378(57.7)$ \\
\hline LHR 31Asn allele & $1177(44.8)$ & $1434(40.4)$ & $3210(42.3)$ \\
\hline \multicolumn{2}{|c|}{ OR LHR 312Asn } & $\begin{array}{c}1.12(1.08-1.33) \\
p<0.001\end{array}$ & $\begin{array}{c}1.11\left(\begin{array}{c}(1.01-1.21) \\
\mathrm{p}=0.03\end{array}\right.\end{array}$ \\
\hline
\end{tabular}

${ }^{a}$ Numbers in cells may not add up due to incomplete genotyping

${ }^{\mathrm{b}}$ Median age at assessment in years 